\title{
Incidence of Contamination of Water Resources in the Development of Livestock Activities in the Lower Area of the Coata River Watershed, Peru
}

\author{
Julio Cesar Quispe-Mamani ${ }^{*}$, Santotomas Licimaco Aguilar-Pinto ${ }^{2}$, Carmen Nievez Quispe-Lino ${ }^{3}$, Ysrael \\ Alberto Tuesta-Ramirez ${ }^{4}$, Olimpia Tintaya-Choquehuanca ${ }^{5}$ \\ 1,2,3,4,5 National University of Altiplano, Peru \\ *jcquispe@unap.edu.pe
}

\begin{abstract}
The objective of the research was to determine the main environmental pollutants affecting the water resource of the lower Coata watershed, for which the descriptive, correlal and explanatory methodology was applied, using The Multinomial Logit regression with survey information applied to $\mathbf{3 8 0}$ heads of families. It was determined that the existence of water pollution has an impact on the volume of production of livestock activity in the lower part of the watershed in a negative manner, this is supported by the dumping of pathogens into the river, which affects 4 units of sheep and cattle heads. The practice of livestock activity directly influences the economic income of families in the lower part of the watershed and explains in 4.12 soles and the main environmental pollutants affecting the water resource in the lower part of the watershed are fecal coliforms and arsenic at a high level.
\end{abstract}

Keywords: Water pollution, Livestock activity, Production, Sustainability, Policies

\section{Introduction}

Environmental pollution of rivers has been a problem in the progress of certain economic activities as in their processes they use various chemicals with composition of significant portions of heavy metals (Xu et al., 2013; Yuan et al., 2019; Zhang et al., 2015). These processes generate outputs such as emissions, effluents and waste, where not all occasions have an adequate final ease; having as the final receptor the bodies of water (Acey, 2013; Bustamante-González et al., 2016; Walker et al., 2013; Wang et al., 2021). In this way, contamination of the water resource is generated, the same one that prevents the use of water for human consumption, irrigation and livestock, this causes a vital shortage of liquid, since it is limited by the quality and not by the amount of the resource (Bustamante et al., 2016; Cervantes-Avilés et al., 2021; Chen et al., 2020; Chiu et al., 2017; Gouin et al., 2019).
In Latin America, the situations driving the problem in water resources are population growth and economic development, which are pressure factors on natural resources and the environment, agricultural border expansion, deforestation, mining, industrialization and urban development (Henriques, 2013; Kervyn et al., 1988; Y. Liu et al., 2019; Zamani-Ahmadmahmoodi et al., 2013). Each of the activities carried out in Latin America demands the supply and availability of large volumes of water, both for human consumption and for the development of agricultural, industrial and general activities all those related to economic development which provide a basis for social security (Álvarez-Buylla, 2017; Arnold et al., 1998; Lustig et al., 2012; Wambua et al., 2014).

In Peru, water pollution and pollution is as old as the development of its cities, as rivers and seawater serve as a final disposal point for sewage evacuations, typical of developing villages (Kervyn et al., 1988; Wu et al., 2021). However, the need to promote sustainable development has made legislation consider the application of mechanisms that provide security for investments and have to be articulated with the normability of water resources, the latter fundamental axis for the use and sustainability of the resource; deterioration in the quality of water resources associated with the development of population and productive activities, among others; involve the design of regulatory and management instruments to enable effective monitoring and monitoring of the quality of water resources (Ferguson \& Morales, 2010; Santos et al., 2020; Tayyebi et al., 2016).

In recent years in the Puno region, environmental and watershed pollution problems have increased, making it one of the causes of frequent mobilizations calling for environmental protection by people and the recovery of water quality through wastewater treatments (Cervantes- 
Avilés et al., 2021). Water is an indispensable resource for life, agriculture, livestock and the environment; "The Coata river watershed is the source of water for human consumption, but it presents pollution on the banks of the Coata river, upstream of the catchment, the article aims to estimate the economic value of water for consumption in Juliaca by applying the contingent valuation method (MVC), reaching conclusions that the availability to be paid by Juliaca families for the protection and surveillance of the Rio Coata is 12.29 suns per month" (Gutierrez, 2018; Huacani, 2019; Quispe, 2015).

Increased development of mining activity, the industrial sector and populations located in the vicinity of rivers, cause pollutants explaining the hardness and microbiological contamination of water which is an important factor to consider for the production of livestock activity (Gouin et al., 2019; Iwan et al., 2017; J. Liu et al., 2021). The contaminated waters that flow into the river come from the oxidation lagoons of Juliaca and the Torococha river affecting the agricultural production of the Coata, Huata and Capachica districts. Another problem, although very little researched is due to the washing of vehicles carried out by the surrounding population especially in Juliaca near the Wonder Bridge (Gutierrez, 2018; Huacani, 2019).

In addition, because the majority of the population under study is engaged in livestock in Cattle in greater proportion than sheep, pigs, among other animals for the production of meat and milk, from which other products such as cheese, yogurt to obtain income are derived and thus cover their different needs. However, pollution negatively affects the main activity that is the livestock sector, in which cattle predominate because of their dairy production. It is therefore important to know the impact of environmental pollution on the volume of production of livestock activity in the lower Coata watershed.

The physical characteristics of the water such as the greenish and cloudy coloration of the water, the yellowing of the rocks within the Coata river indicates pouring of sewage and presence of heavy metals, as well as solid residues and inadequate use of water. The population of affected districts such as Huata, Coata and Capachica coexist with these environmental problems day by day and can do little to prevent the presence of suspended metals and solids in the water source of the Coata watershed from damaging irrigation systems as well as agricultural and livestock areas, since the areas that were irrigated with these waters are evidenced the presence of relaves on the irrigated surfaces , degrading soil quality and damaging agriculture and livestock in the area (Altieri \& Nicholls, 2000; Bustamante-González et al., 2016; Riera, 2013). Hence the problem exists is the high degree of water pollution in the lower Part of the Coata river watershed.

It is necessary to determine the effects of the environmental pollution of the aforementioned watershed on the livestock activity and then analyze and calculate the consequences that fall on this activity carried out by the inhabitants in terms of quantity, production, quality and livestock performance that consequently has a certain influence in the economic income to the families that provide the products to the local markets and is consumed by residents of the area; Since this watershed causes a decrease in livestock productivity, as well as a deterioration in the quality of the products obtained from livestock in that sector, the yield of forage pasture crops has declined and milk production is impaired, which which, in turn, has the effect that sustainable development for the inhabitants is non-existent in this area as they have been in the midst of water contamination for several years. Since water is the main factor in the health and nutrition of the animal and also as an element for the hygiene of the facilities where the animals are (Quispe, 2015).

A high degree of environmental pollution in this area, in addition to affecting the quality of life of people, has been affecting natural resources such as soil, flora, fauna and mainly water, which is very important for the nutrition of livestock, thus causing the yields of livestock activity to decrease by negatively influencing production and in turn, causing a decrease in the economic incomes of families in this sector, causing the quality of life of the population not to be the best.

The research questions raised were: What are the main environmental pollutants affecting the water resource in the lower Coata watershed?, How is the impact of water pollution on the 
volume of production of livestock activity in the lower Coata watershed? and how is the influence of livestock activity on the economic incomes of families in the lower Coata watershed? Therefore, the objective of the research was to determine the main environmental pollutants affecting the water resource in the lower Coata watershed, to determine the incidence of water pollution on the volume of production of livestock activity in the lower Coata watershed, and to determine the influence of livestock activity on the economic incomes of families in the lower Coata watershed.

\section{Literature Review}

\section{Cobb Douglas model related to production}

The production function presented below will be developed using the Methodology of Minimum Ordinary Squares, a system of linearized equations was built with natural logarithm of the Cobb-Douglas function that has the following form (Altieri \& Nicholls, 2000):

$$
\begin{aligned}
& (Y)=L(A)+\alpha \operatorname{Ln}(N I)+\beta \operatorname{Ln}(L)+\delta \operatorname{Ln}(M W) \\
& \operatorname{Ln}(M W)=\operatorname{Ln}(w g a g)+\operatorname{Ln}(w g h)+ \\
& \operatorname{Ln}\left(w g \_m\right)+\operatorname{Ln}(w g s)+\operatorname{Ln}(w g g) \\
& \operatorname{Ln}(L)=\operatorname{Ln}(P B I p p A)
\end{aligned}
$$

$$
\begin{gathered}
\operatorname{Ln}(w g w)=\operatorname{Ln}(w w g)+\operatorname{Ln}(r w g)+ \\
\operatorname{Ln}(w g c)+\operatorname{Ln}(w g m q)+\operatorname{Ln}(w g e)
\end{gathered}
$$

Where:

$Y=$ Production of (x-crop) in thousands of tons

$N I=$ Net national investment in non-financial assets

$L=$ Agricultural work in a number of workers

$M W=$ Municipal waste in thousands of tons

$w g a g=$ Waste generated by agriculture in thousands of tonnes

$w g h=$ Household-generated waste in thousands of tons

$w g m=$ Waste generated by manufacturing industry in thousands of tons

$w g s=$ Waste generated in the service industry in thousands of tons

$w g w=$ Waste generated by water disposal in thousands of tons

$w w g=$ Waste generated by wood waste in thousands of tons

$r w g=$ Recyclable waste generated in thousands of tons

$w g c=$ Waste generated by construction in thousands of tons $w g m q=$ Waste generated by mines and excavation in thousands of tons

$w g e=$ Waste generated by electricity, gas, steam and air conditioning in thousands of tons

$P I B P P A=$ Gross domestic product per capita at purchasing power parity values in dollar.

The built model helps to identify an approximate form of the production function of ( $\mathrm{x}=\mathrm{crop}$ ), however, the data have many limitations due to the lack of the disposition of data that is necessary for the regression of that model. So agricultural activity has become intense because of high population growth; livestock activity is a supply-driven sector, livestock production has a rapid growth by high demand for meat; global meat production is 229 million tonnes and will be doubled by 2050 , and dairy tends to rise from 580 million to 1043 million tonnes in the same period. Around the watershed is 18670 cattle heads with growth over time(Jiménez Sotelo, 2018; Labandeira et al., 2007).

\section{Environmental pollution}

It is the direct or indirect introduction into the environment by man of any type of hazardous waste that may be harmful to human health or plant or animal life, damage ecosystems, hinder the enjoyment of places of recreation or hinder other legitimate uses of the environment. Pollution is the presence of harmful and annoying substances in the air, water and soils, deposited there by human activity, in such quantity and quality, that they can interfere with the health and well-being of man, animals and plants, or impede the full enjoyment of life (Encinas, 2011).

\section{Water contamination}

Water has always been a vital resource for man, at first only as a drink, later for washing and also for irrigation. With the power provided by fossil fuels and modern technology, humanity has diverted riverbeds, extracted groundwater and contaminated Earth's water sources as it had never done before (Encinas, 2011).

\section{Main water pollutants}

Pathogenic microorganisms: are the different types of microorganisms (bacteria, viruses, 
protozoa and other microscopic organisms) that transmit diseases. In developing countries, diseases caused by these pathogens are one of the most important reasons for premature death, especially children. Normally these microbes reach the water in the stool and other organic remains produced by infected people. For this reason, a good index for measuring the health of the waters, as far as these microorganisms are concerned, is the number of coliform bacteria present in the water. WHO (World Health Organization) recommends that there be 0 colonies of coliforms per $100 \mathrm{ml}$ of water in drinking water. These microorganisms are often the result of internal activities of oil-exploiting companies (Garros \& Borla, 2020).

Organic waste: they are the set of organic waste produced from processes that are not directly related to the extraction of hydrocarbons, but are part of the internal processes of oil companies for the maintenance of the personnel who work for this type of companies and generate this type of waste, for example food consumption, wastewater treatment plants that generate feces and other materials that can be decomposed by aerobic bacteria, that is, in processes with oxygen consumption. When this type of waste is in excess, the proliferation of bacteria depletes oxygen, and fish and other living beings that need oxygen can no longer live in this water. Good indices to measure contamination by organic waste are the amount of dissolved oxygen, in water, or the biological oxygen demand (Garros \& Borla, 2020).

Inorganic chemicals: This group includes acids, salts and toxic metals such as mercury and lead. If they are in high quantities they can cause serious damage to living beings and are the result of oil separation processes in their derivatives and generate high impact on the waters and generally on the environment.

Inorganic plant nutrients: Nitrates and phosphates are water-soluble substances that plants need for their development, but if they are in excessive quantity they induce the excessive growth of algae and other organisms causing eutrophication of water. When these algae and other vegetables die, being broken down by microorganisms, oxygen is depleted and the lives of other living beings become impossible. The result is smelly and unusable wáter.

Inorganic compounds: Many inorganic molecules such as oil, gasoline, plastics, pesticides, solvents, detergents, etc. end up in the water and remain, in some cases, long periods of time, being man-made products, have complex molecular structures difficult to degrade by microorganisms.

Sediments and suspended materials: Many particles ripped from the ground and dragged into the water, along with other materials that are suspended in the waters, are, in terms of total mass, the largest source of water contamination. The turbidity they cause in the water makes life difficult for some organisms, and the sediments that accumulate destroy feeding or dusting sites of fish, fill lakes or swamps and clog canals, rivers and ports.

Metal contamination: Heavy metals are one of the most dangerous environmental pollutants, because they are not biodegradable and their potential bioaccumulation in living organisms. Among them, they stand out are mercury, cadmium and lead. Wastewater discharge certain steel industries, surface treatment, tanning, etc., are classic examples of heavy metal contamination.

Biochemical Oxygen Demand: High BOD values demonstrate a high concentration of biodegradable organic matter, plus there is a decrease in oxygen because microorganisms are consuming dissolved oxygen in water. The higher the biochemical demand for oxygen, the more polluting the sample is.

\section{Effects of environmental pollution}

Water pollutants, whether introduced domestically, industrially or agriculturally, can generally produce numerous types of effects to be studied depending on the use to be given to water, or within the perspective of having better quality waters, in order to preserve aquatic life and to be able to dedicate it for recreational or purely aesthetic purposes (Garros \& Borla, 2020).

Effects caused by suspended solids: Suspended solids absorb solar radiation, reducing the 
photosynthetic activity of aquatic vegetation. At the same time they obstruct the waterways, reservoirs and lakes. They also intervene in industrial production processes and can corrode materials and increase the cost of water purification (Garros \& Borla, 2020).

Effects caused by phenols: Fish, especially fat species such as trout, salmon and eels, accumulate them. But the biggest problem is that when they reach conventional chlorination plants they give rise to chlorine phenols, conferring to the water a very unpleasant taste even in units of parts per million (Garros \& Borla, 2020).

Effects caused by fats and oils: The fact that they are less dense than water and immiscible with it, causes them to spread over the surface, so that small amounts of fats and oils can cover large areas of water. In addition to producing an aesthetic impact, they reduce reoxigeation through the air-water interface, decreasing dissolved oxygen and absorbing solar radiation, affecting photosynthetic activity and, consequently, internal production of dissolved oxygen. They make purification treatments more important, and some oils, especially minerals, are often toxic (Garros \& Borla, 2020).

Effects caused by detergents: It is not only bioconcentration the environmental problem, so is oxygen access to the water mass, due to foam on its surface and increasing the toxicity of 3.4benzopirene, another micro pollutant of enormous carcinogenic action. The real environmental problem caused by detergents lies in polyphosphate, included in its formulation to soften water.

Effects caused by hydrocarbons: The most noteworthy for their danger are polycyclic aromatic hydrocarbons (PAH's), (condensed aromatic nuclei), not only present in very small amounts in oil but also in fir and beech forests. They are carcinogenic and, in particular, the benzopirene that is the best studied, in which you have observed a short period of latency. In the water treatment process one part is usually eliminated in the filtration flocculation and the other in oxidation, leaving very little in the treated water. It seems that detergents enhance their toxicity, as has been said before. Despite its chemical inertia its biodegradation has been proven, although slow (Garros \& Borla, 2020).

Effects on livestock activity: By pollution of the waters of the watershed livestock and agriculture is affected as the rates of production of meat, milk, are reduced, affecting the incomes of families deteriorating the standard of living of the population. It is therefore necessary to raise public awareness of the need to take over the treatment of domestic wastewater, in order to reduce the negative health and environmental impacts resulting from inadequate management, as well as the benefits of guiding their use in productive activities, which mean healthy food, employment and greater availability of good quality wáter (Garros \& Borla, 2020).

\section{Methodology}

The application of the hypothetical-deductive method for which the collection of information requires the specific design of surveys that evaluate the specific determinants of environmental pollutants in the livestock sector. Therefore, the data collection tool will be a survey structured in two blocks: considering the education, socio-economic aspect of the interviewee and the environment(Hernández et al., 2010).

The collection of the necessary information on the area of impacts of environmental pollution, analyzing the socio-economic aspects. In the field phase, the surveys were carried out to find the information provided by the population; identification of areas where there is contaminated area with biotic and abiotic characteristics of the area, in addition tozoning the study area according to the radius of affectation of each area identified as contaminated area.

The methodological design applied in this research is descriptive, correlal and explanatory (Mendoza, 2014). Since data will be analyzed using a binary regression model, specifically the Minimum Ordinary Tables (MCO) model and the multinomial logistic regression model.

The methodology applied is descriptive and correlal because it describes the particularity and magnitude of the problem, where the variables are evaluated in a specific period, analyze data 
obtained at any given time based on the detailed collection of information, the central objective of the methodology is to establish the correlations between the concepts and variables of description of the phenomenon in question, in order to build correlal type research models where the essential objective is detailed determination of the strength level of correlations between independent and dependent variables (Cazau, 2006).

\subsection{Sample of study object}

The universe of study is made up of all tributants (rivers and ravebs), soils and communities located in the lower Coata watershed (Table 1).

Table 1. Study sample

\begin{tabular}{cl}
\hline District & Rural Pob. \\
\hline Juliaca & 10983 \\
Caracoto & 5591 \\
Huata & 2785 \\
Coata & 4717 \\
Capachica & 6420 \\
\hline Total & 30496 \\
\hline
\end{tabular}

Source: INEI- Own Elaboration

The inclusion criteria for determining the samples are that these are part of the communities near the rivers of the Coata river and that the communities where the only source of water used as a livestock drink is from the Coata river. Therefore, the following formula was applied for the calculation of the sample:

$$
n=\frac{Z^{2} p * q(N)}{(N-1) e^{2}+Z^{2}(p * q)}
$$

Developing the above formula with the aforementioned data, it was determined that the sample number is: $n=380$, out of a total of 30,496 inhabitants, which were mentioned by the National Institute of Statistics and Informatics.

\section{Results and discussion}

The lower Area of the Coata river watershed is considered one of the dairy areas of the Puno region, supplying demand from local markets in the Puno region. A rural sector that contributes to food security at the local and regional levels. Similarly, peasant families are actors in the sustainability of plant and animal biodiversity, highlighting the latest.

In this sense, considering the gender of the population studied is that, of the total number of respondents, $66.6 \%$ are male, while the remaining (33.3\%) represent women. In the case of years of education, 48 respondents were found who did not study any year, either in an initial, primary, secondary and higher school. However, it was found that 4 respondents who studied over 15 years that are categorized with level of university education and on average the studied population has 6 years of educational training, i.e. with primary level (Table 2).

In addition, according to Table 2, the highlight is in economic income per family, where of the total number of respondents, about $50 \%$ of respondents claimed to have median income amounting to less than or equal to S/. 930.00 soles, 39.2\% have incomes less than S/. 450.00 soles, $13.4 \%$ have economic incomes above $\mathrm{S} /$. 930.00 soles.

Considering as important the case of the development of livestock and productive activity, the population of this watershed is engaged in the rearing of cattle, sheep, minor animals, among others, where when considering cattle it is for the purposes of milk and meat production, in this sense according to the table above it can be inferred that the production of milk by number of head of cattle significantly influences the level of income of families, due to its sale but at chacra prices, since many families get to produce up to 15 litres of milk per cow per day. The limitation to ensure the development of livestock activity is feeding for livestock, in this sense it takes advantage of existing natural pastures just as there are few plots with cultivated pasture production, in addition to the production of oat fodder and barley especially, where their production is not intensive but complemented by the purchase of these from the communities near the watershed, the volume of beef production, has a minimum of 1 and a maximum of 15 units, in the volume of sheep production was found families (26 families) who did not have any of them, but families were found (3), who had sheep greater than 25 units (Table 2). 
Table 2. Descriptive statistics

\begin{tabular}{lccccc}
\hline \multicolumn{1}{c}{ Variable } & $\mathrm{N}$ & Mínimum & Maximum & Mean & $\begin{array}{c}\text { Standard } \\
\text { deviation }\end{array}$ \\
\hline Age of the respondent & 380 & 21.00 & 79.00 & 51.96 & 12.81 \\
\hline Gender of the respondent & 380 & 0.00 & 1.00 & 0.67 & 0.47 \\
\hline Years of education & 290 & 0.00 & 15.00 & 5.79 & 4.19 \\
\hline Respondent's income & 380 & 61.60 & $1,700.00$ & 593.06 & 344.98 \\
\hline Milk production / family & 380 & 0.00 & 60.00 & 27.16 & 17.30 \\
\hline Barley production / family & 380 & 0.00 & 70.00 & 56.66 & 9.60 \\
\hline Soil type & 380 & 1.00 & 3.00 & 1.62 & 0.84 \\
\hline Water Pollution Level & 380 & 2.00 & 4.00 & 3.28 & 0.56 \\
\hline Oat production & 380 & 0.00 & 100.00 & 7.08 & 16.41 \\
\hline Volume of cattle production & 362 & 1.00 & 15.00 & 8.17 & 4.25 \\
\hline Use or not of fertilizer & 380 & 0.00 & 1.00 & 0.42 & 0.49 \\
\hline Arsenic level & 380 & 1.00 & 3.00 & 2.41 & 0.91 \\
\hline Nitrate & 380 & 1.00 & 1.00 & 1.00 & 0.00 \\
\hline Biochemical Oxygen Demand & 380 & 21.37 & 30.92 & 25.84 & 4.74 \\
\hline Total Coliforms & 380 & $7,140.00$ & $9,720.00$ & $8,146.47$ & $1,251.78$ \\
\hline Hydrogen Potential & 380 & 1.00 & 3.00 & 2.28 & 0.85 \\
\hline Aluminum Grade & 380 & 1.00 & 1.00 & 1.00 & 0.00 \\
\hline Fecal Coliforms & 380 & 1.00 & 3.00 & 1.77 & 0.98 \\
\hline Total Coliforms & & 1.00 & 1.00 & 1.00 & 0.00 \\
\hline Iron Grade & 380 & 1.00 & 1.00 & 1.00 & 0.00 \\
\hline Sheep production volume & 380 & 0.00 & 27.00 & 10.16 & 6.96 \\
\hline Liters of bovine water & 380 & 0.00 & 750.00 & 389.34 & 224.78 \\
\hline Manganese Grade & 380 & 1.00 & 3.00 & 1.47 & $84,813.00$ \\
\hline Liters of water consumed by sheep cattle & 355 & 0.00 & 162.00 & 65.17 & 39.82 \\
\hline
\end{tabular}

The practice of agricultural and livestock activity, it is necessary to count as potential the natural resources and their elements of the watershed, so it is important to guarantee the quality of the resources, and the soil becomes a high value element in the process of producing bread products or for the production of food for livestock; of which then, the predominant soil type in the study areas is sandy soil, because it represents $62.1 \%$, followed by clay and salt soil type representing $23.7 \%$ and $14.2 \%$, respectively (Table 2).

The practice of using fertilizers for the production of fodder or pastures for livestock or to ensure the production of household food products is lower than average in the lower area of the watershed, where $57.9 \%$ of respondents indicated that they do not use chemical fertilizers when conducting their agricultural activities, while $42.1 \%$ of respondents do not use fertilizers, all this to prevent pests from maloguing their agriculture mainly, complementaryly using natural fertilizers and natural fertilizer or manure of cattle and sheep (Table 2).

In climate change it is now evident at the account-wide level and this is reflected by the scarcity of water reure, which is vital for man's survival and livestock rearing, in this sense it becomes important as a representative variable for the development of productive activities and the conservation of natural resources. However, the urban territorial development of the cities near the watershed has been adversely affecting, polluting all the potential resources available, and the hardest-hit is the hybrid resource but despite that the water consumption (in liters) by cattle and other animals remains affected, where the minimum consumption is 501ts and the maximum is 750 lts (Table 2). 
Table 3. Water Pollution Level

\begin{tabular}{lcc}
\hline \multicolumn{1}{c}{ Description } & Frequency & Percentage \\
\hline Average water pollution level & 22.00 & 5.80 \\
\hline High level of water pollution & 230.00 & 60.50 \\
\hline Very high level of water pollution & 128.00 & 33.70 \\
\hline Total & 380.00 & 100.00 \\
\hline
\end{tabular}

In this regard, when consulting on the level of pollution of the water resource to the population under study, these have a definite perception of water pollution level, where $60 \%$ of respondents recognize that water pollution is high (worrying), while $33.7 \%$ of respondents say water pollution is high (alarming) and only 5.8\% mention that water pollution is average (Table 3 ).

In determining the incidence of water pollution on the volume of production of livestock activity in the lower Coata watershed, it was considered as a starting point that the area under study is purely livestock and a low percentage in agricultural activities of different products that are mostly self-

\section{Production volume (cattle and sheep) $=\beta_{0}+\beta_{1}$ Soil type $+\beta_{2}$ Oat production volume $+\beta_{3}$ Existence of water pollution $+\mathrm{u}$}

Regressing the linear regression model (MCO), in which an R-square of 0.3132 is presented indicating that $31.32 \%$ is the adjustment of the model to its data or that by $31 \%$ is the variation of the response variable that explains its relationship to the predictor variables; analyzing the P-value to consumption; it is mostly fodder for the food of its cattle and sheep.

Of which, the dependent variable is the volume of production of livestock activity measured per head of cattle and sheep. Independent variables are the type of soil that positively influences the amount of forage production for livestock which comes to be represented by clay, sandy, stony and black soil; volume of oat production; water pollution, where its influence is directly on productivity; oat production, which positively affects the volume of beef production by having more food. Therefore, the approach of the econometric model for this objective was given by simple linear regression, taking the following:

Table 4. Simple linear regression of hypothesis specifies 1

\begin{tabular}{lcccccc}
\hline Linear regression & & & & & $\begin{array}{r}\text { Number of observations }=380 \\
\mathrm{~F}(3,376)=69.20\end{array}$ \\
& & & & & $\begin{array}{r}\text { Prob }>\mathrm{F}=0.0000 \\
\text { R-squared }=0.3132 \\
\text { Root MSE }=3.5352\end{array}$ \\
\hline $\begin{array}{l}\text { Production volume } \\
\text { (cattle and sheep) }\end{array}$ & $\begin{array}{c}\text { Coefficien } \\
\mathrm{t}\end{array}$ & $\begin{array}{c}\text { Standard } \\
\text { error }\end{array}$ & $\mathrm{T}$ & $P>|t|$ & $\begin{array}{c}\text { [95\% confidence } \\
\text { interval] }\end{array}$ \\
\hline Soil type & .6990602 & .2359718 & 2.96 & 0.003 & .2349951 & 1.163125 \\
\hline $\begin{array}{l}\text { Oat production } \\
\text { volume }\end{array}$ & .0423852 & .0119103 & -3.56 & 0.000 & -.0658082 & -.0189623 \\
\hline $\begin{array}{l}\text { Existence of water } \\
\text { contamination }\end{array}$ & -3.929248 & .3060554 & -12.84 & 0.000 & -4.531141 & -3.327356 \\
\hline Constant & 22.94492 & 1.283216 & 17.88 & 0.000 & 20.42134 & 25.46851 \\
\hline
\end{tabular}


Therefore, by analysing the coefficients, it can be determined that the existence of water pollution affects the volume of production of livestock activity in the lower area of the Coata watershed but in a negative way, since if water pollution increases by pouring pathogens into it, then the volume of production of cattle and sheep will decrease by 4 heads. In addition, the type of soil has much to do with this relationship, since it was determined that there is a positive relationship between the type of soil with the volume of production of cattle and sheep, which implies that if the quality of the soil type improves, then the volume of livestock and sheep livestock production would increase by one unit. In addition, the volume of oat production has a positive relationship with the volume of production of cattle and sheep, implying that if oat production is high, then the production volume will increase by 0.042 units.

In order to determine the influence of livestock activity on the economic income of families in the lower Coata watershed, the linear regression model (MCO) was equally considered, dependent variable is family economic income, categorical and/or highlighting. The independent variables were the gender level of education and volume of production of cattle and sheep. Therefore, the model proposed was as follows:

\section{Family income $=\beta_{0}$ Age $+\beta_{1}$ Level of education $+\beta_{2}$ Production volume of livestock (cattle and sheep) $+\mathrm{u}$}

The results obtained from the model are presented below.

Regressing the model (MCO) for this case obtained an R-square of 0.3134 indicating that
$31.34 \%$ is the adjustment of the model to its data or that $31 \%$ is the variation of the response variable that explains its relationship to the predictor variables (Table 5).

Table 5. Simple linear regression of hypothesis specifies 2

\begin{tabular}{lcccccc}
\hline Linear regression & & & & & $\begin{array}{c}\text { Number of observations }=380 \\
\mathrm{~F}(3,376)=37.13\end{array}$ \\
& & & & & $\begin{array}{c}\text { Prob }>\mathrm{F}=0.0000 \\
\text { R-squared }=0.3134 \\
\text { Root MSE }=258.87\end{array}$ \\
\hline $\begin{array}{l}\text { Family economic } \\
\text { income }\end{array}$ & $\begin{array}{c}\text { Coefficien } \\
\mathrm{t}\end{array}$ & $\begin{array}{c}\text { Standard } \\
\text { error }\end{array}$ & $\mathrm{T}$ & $P>|t|$ & \multicolumn{2}{c}{$\begin{array}{c}\text { [95\% confidence } \\
\text { interval] }\end{array}$} \\
\hline $\begin{array}{l}\text { Production volume } \\
\text { (cattle and sheep) }\end{array}$ & 4.125147 & 4.028954 & 1.02 & 0.0307 & -3.807281 & 12.05757 \\
\hline Age & -3.011874 & 1.504676 & -2.00 & 0.046 & -5.974363 & -.0493849 \\
\hline Education level & 36.11183 & 4.531368 & 7.97 & 0.000 & 27.19022 & 45.03343 \\
\hline Constant & 614.6233 & 100.90 & 6.09 & 0.000 & 415.9659 & 813.2808 \\
\hline
\end{tabular}

In addition, it is clear that if the volume of production of cattle and sheep increased in one unit, then the household economic income will increase by 4.12 soles, if the age of the family members increases by 1 year, then the household economic income will decrease by 3,011 soles, this considering that the population of the field of study is mostly occupied by adulthood at higher age and if the level of education of the members increases by a level of education, then the household economic income will increase by 36.11 soles, showing itself in this way that this variable is very important in family development and the improvement of the quality of family life (Table 5).

Finally, in order to determine the main environmental pollutants affecting the water resource of the lower Coata watershed, the multinomial logit model was considered, where the dependent variable is water pollution, which is represented by the level of pollution presented by water resources assessing whether it is quality, presence of heavy metals, the potential of hydrogenoids, the perception of the level of 
pollution by the inhabitants; data that was obtained from survey information. The independent variables considered were um/L of total coliforms, liters of water consumed by livestock, manganese, um/L of fecal coliforms, biochemical oxygen demand (BOD) and arsenic (Table 6).

Table 6. Estimate of the multinomial logit model for the overall goal

\begin{tabular}{|c|c|c|c|}
\hline Number of observations: 380 & & & Pseudo R2=0.2177 \\
\hline Contamination level & $\begin{array}{l}\text { Low pollution } \\
\text { level }\end{array}$ & $\begin{array}{c}\text { Average pollution } \\
\text { level }\end{array}$ & High pollution level \\
\hline Variables & Coefficient & Coefficient & Coefficient \\
\hline um / L of total coliforms & - & 0.0121943 & -0.006044 \\
\hline $\begin{array}{l}\text { Liters of water consumed } \\
\text { by livestock }\end{array}$ & - & 0.0012711 & 0.0076367 \\
\hline Manganese & - & 0.7591984 & -0.2716239 \\
\hline um / L of fecal coliforms & - & -14.8305 & 8.482446 \\
\hline $\begin{array}{l}\text { Biochemical oxygen } \\
\text { demand (BOD) }\end{array}$ & - & 1.693971 & -1.093971 \\
\hline Arsenic & - & -1.817472 & 0.0378528 \\
\hline Constant & - & -73.38035 & 36.51797 \\
\hline
\end{tabular}

Of which, it is evident Pseudo R2 21.77, which as a measure of goodness of adjustment is, this because the level of water pollution has an impact on livestock activity when explained in a grouped way, since a combination of them are the ones that have even more effect on the contamination of this, the constant has a high coefficient because there is also influence on the part of climate change, the disappearance of flora and fauna and soil pollution (Table 6).

Analyzing the $\mathrm{um} / \mathrm{L}$ of total coliforms, it is considered that if it increases by $1 \mathrm{um} / \mathrm{L}$, then the probability that the level of contamination of the water resource will increase to $1.21 \%$ and decrease by $0.6 \%$ for the level of contamination of the water resource is high; in the case of litres of water consumed by cattle and sheep, it is considered that if water consumption by livestock increases by 1 litre, then the level of water pollution is likely to increase to $0.1 \%$ and increase to $0.7 \%$ for the level of water resource contamination to be high (Table 6).

In the case of manganese, it is considered that if it increases by $1 \mathrm{ug} / \mathrm{L}$, then the probability that the level of water contamination will increase to $75.91 \%$ and decrease by $27.16 \%$ for the level of water contamination is high. Analyzing the um/L of fecal coliforms, it is considered that if it increases by $1 \mathrm{um} / \mathrm{L}$, then the probability that the level of contamination of the water resource is average will decrease by $1483.05 \%$ and increase by $848.24 \%$ for the level of contamination of the water resource to be high. For DBO, it considers that if it increases by $1 \mathrm{mgO} 2 / \mathrm{L}$, then the likelihood that the level of water contamination will increase by $169.39 \%$ and decrease by $109.39 \%$ for the level of water contamination to be high and for arsenic, considers that if it increases by $1 \mathrm{~g} / \mathrm{L}$, then the likelihood that the level of water pollution will decrease by $181.74 \%$ and increase by $3.78 \%$ for the level of water contamination to be high. In this sense, it can be concluded that environmental pollution of the water resource is mainly affected by the shedding of faecal coliforms in the city of Juliaca, and represents a range of contamination between medium and high (Figure 1).

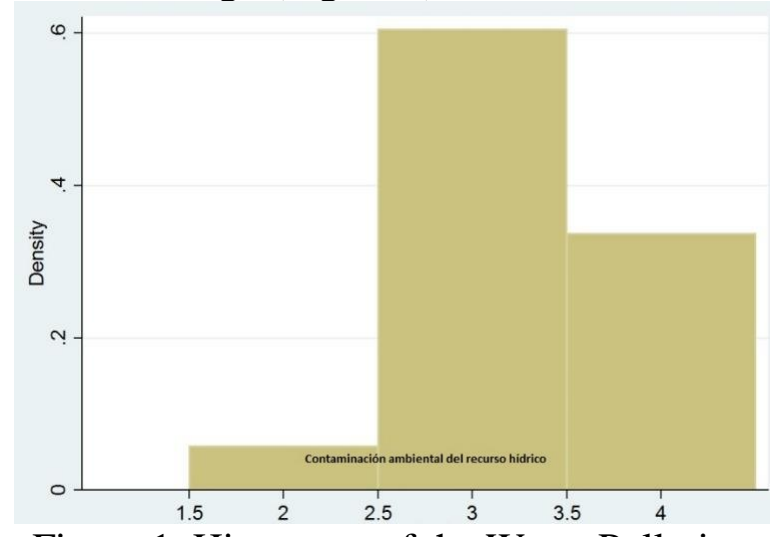

Figure 1. Histogram of the Water Pollution variable 
The results obtained in our research are closely consistent with the research carried out by Machaca (2014), where the care determined that pollution from garbage and mining pollution generate pollution in the Coata river, this as a result of flora and fauna; villagers who live on the sidelines of the river and engage in agricultural activities, especially milk and cheese production which are affected to have a quality standard of living; in 2003 monitoring was carried out in the Coata river watershed by PEBLT which made measurement as to the physical, chemical, bacteriological aspect obtaining the results in time to a difference in turbidity in river Torococha and Coata; not suitable for human consumption, high alkalinity rate, acidity, dissolved solids, ammoniacal nitrogen, mercury resulting in a high rate of child morbidity and general; increased water-borne diseases; regional and local institutions must fulfill their roles.

In addition, it is consistent with what is determined by Gutierrez (2018), where when assessing the water quality of the Coata river at the mouth of Torococha - Juliaca using the water quality index of the Canadian Council of Ministers of the Environment (CCME-WQI) and the water quality index of water resources in Peru (ICA-PE); where when monitoring the parameters of $\mathrm{PH}$, dissolved oxygen, conductivity, aluminum, arsenic, boron, cadmium, among other metals during the last quarter of 2018 , determining that the torococha river negatively influences the quality of the Coata river.

In considering Bustamante et al. (2016) evidence that the increase in gold production causes concern, as many mines discharge untreated water and waterways directly into the waterways, and it requires large volumes of water. This situation has aroused concern in communities whose economy has been affected, as water affecting rivers is determined not only to meet their needs, but also in agriculture for crop irrigation. Water is essential to carry out daily activities and for the economy. This requires helping to develop a mine plan that should include water and relave management. It is therefore consistent with what is determined about the effects of chemical and solid waste contaminants on the quality of the water resource.
Finally, they agree with the results of Bustamante-González et al. (2016), those who were able to identify as the main source of pollution of the river are the riverside communities, by the discharges of wastewater to the river. Where the population of the user communities of the Tlapaneco river recognizes that it is polluted and affects their health, agricultural production and recreational activities. On the other hand, there is a divergence of opinion as to who should be responsible for the sanitation of the river, and there is a high degree of skepticism about the willingness and responsibility of federal, state and local authorities to solve the problem. An issue that happens the same in the Coata watershed.

\section{Conclusion}

The existence of water pollution affects the volume of production of livestock activity in the lower Area of the Coata watershed in a negative way, since if it increases water pollution by pouring pathogens into it, then the volume of production of cattle and sheep will decrease by 4 heads; there is a positive relationship between the type of soil with the volume of production of cattle and sheep, which implies that if the quality of the soil type improves, then the volume of livestock and sheep livestock livestock will increase by one unit. In addition, the volume of oat production has a positive relationship with the volume of production of cattle and sheep and is explained in 0.042 .

The influence of livestock activity on the economic income of families in the lower Coata watershed occurs directly, since if the volume of cattle and sheep production increases in one unit, then the household economic income will increase by 4.12 soles, if the age of the family members increases by 1 year, then the family economic income will decrease by 3,011 soles and if the level of education of the members increases by one level, then the family economic income will increase by 36,11 soles, thus showing that this variable is very important in family development and the improvement of the quality of family life.

Finally, the main environmental pollutants affecting the water resource of the lower Coata watershed are faecal coliforms, where it is 
considered that if it increases by $1 \mathrm{um} / \mathrm{L}$, then the probability that the level of contamination of the water resource will decrease by $1483.05 \%$ and increase by $848.24 \%$ for the level of water contamination to be high; and arsenic, where if it increases by $1 \mathrm{~g} / \mathrm{L}$, then the probability that the level of water contamination will decrease by $181.74 \%$ and increase by $3.78 \%$ for the level of water contamination to be high.

\section{References}

[1] Acey, C. (2013). The Political Ecology of Watershed Depletion and Contamination in Rural Ghana. https://papers.ssrn.com/abstract=2236761

[2] Altieri, M., \& Nicholls, C. (2000). Agroecología: teoría y práctica para una agricultura sustentable. http://www.sidalc.net/cgibin/wxis.exe/?IsisScript=orton.xis\&metho $\mathrm{d}=$ post $\&$ formato $=2 \&$ cantidad $=1 \&$ expresio $\mathrm{n}=\mathrm{mfn}=072950$

[3] Álvarez-Buylla, E. R. (2017). La ecología evolutiva del desarrollo en México. Scielo.Org.Mx.

http://www.scielo.org.mx/scielo.php?script =sci_arttext\&pid=S1870-

34532017000500014

[4] Arnold, J. G., Srinivasan, R., Muttiah, R. S., \& Williams, J. R. (1998). Large area hydrologic modeling and assessment part I: Model development. Journal of the American Water Resources Association, 34(1), 73-89. https://doi.org/10.1111/j.1752-

1688.1998.tb05961.x

[5] Bustamante-González, A., Jesús, G. D., Jaramillo-Villanueva, J. L., \& VargasLópez, S. (2016). Percepción de la contaminación del Río Tlapaneco por la población ribereña. Agricultura, Sociedad y Desarrollo, 13(1), 47-62. http://www.scielo.org.mx/scielo.php?script =sci_arttext\&pid=S187054722016000100047

[6] Bustamante, N., Danoucaras, N., McIntyre, N., Díaz-Martínez, J. C., \& Restrepo-Baena, O. J. (2016). Review of improving the water management for the informal gold mining in Colombia. Revista
Facultad de Ingeniería Universidad de Antioquia, 79, 163-172. http://www.scielo.org.co/scielo.php?pid=S 0120 -

62302016000200016\&script=sci_arttext\&t lng=en

[7] Cazau, P. (2006). Introducción a la investigación en ciencias sociales (Tercera Ed).

http://www.academia.edu/download/37844 523/cazau_-_metodologia.pdf

[8] Cervantes-Avilés, P., Durán Vargas, J. B., Akizuki, S., Kodera, T., Ida, J., \& CuevasRodríguez, G. (2021). Cumulative effects of titanium dioxide nanoparticles in UASB process during wastewater treatment. Journal of Environmental Management, 277.

https://doi.org/10.1016/j.jenvman.2020.11 1428

[9] Chen, T., Liu, Q., Zheng, Y., \& Zhou, L. (2020). Correlation patterns between magnetic parameters and heavy metals of core sediments in the Yellow River Estuary and their environmental implications. Marine Pollution Bulletin, 160.

https://doi.org/10.1016/j.marpolbul.2020.1 11590

[10] Chiu, M. C., Hunt, L., \& Resh, V. H. (2017). Climate-change influences on the response of macroinvertebrate communities to pesticide contamination in the Sacramento River, California watershed. Science of the Total Environment, 581-582, 741-749. https://doi.org/10.1016/j.scitotenv.2017.01 .002

[11] Encinas, M. (2011). Medio ambiente y contaminación. Principios básicos (1 ra ed.).

[12] Ferguson, B. G., \& Morales, H. (2010). Latin American agroecologists build a powerful scientific and social movement. In Journal of Sustainable Agriculture (Vol. 34, Issue 4, pp. 339-341). https://doi.org/10.1080/104400410036800 49

[13] Garros, M., \& Borla, S. (2020). Ambiente y pobreza: Una mirada interdisciplinaria. https://books.google.es/books?hl=es\&lr=\& 
$\mathrm{id}=\mathrm{CZPaDwAAQBAJ} \&$ oi $=$ fnd $\&$ pg $=\mathrm{PA} 7$

$\& \mathrm{dq}=$ Contaminación+del+agua+y+sus+ef ectos+en+la+pobreza+y+salud\&ots $=p Q A$ WKn3kSU\&sig=UHsVfcsy0JofaZeI7PID gacUt8w

[14] Gouin, N., Bertin, A., Espinosa, M. I., Snow, D. D., Ali, J. M., \& Kolok, A. S. (2019). Pesticide contamination drives adaptive genetic variation in the endemic mayfly Andesiops torrens within a semiarid agricultural watershed of Chile. Environmental Pollution, 255, 113099. https://doi.org/10.1016/j.envpol.2019.1130 99

[15] Gutierrez Cabana, V. R. (2018). Evaluación de la calidad de agua del río Coata en la desembocadura del río Torococha utilizando el Índice de Calidad de Agua del Consejo Canadiense CCMEWQI y el ICA-PE, Puno-2018. https://repositorio.upeu.edu.pe/handle/UP EU/1771

[16] Henriques, J. M. (2013). On becoming healthier communities: Poverty, territorial development and planning. Elsevier. https://www.sciencedirect.com/science/arti cle/pii/S0870902513000369

[17] Hernández Sampieri, R., Fernández Collado, C., \& Baptista Lucio, P. (2010). Metodología de la investigación (Issue 1). https://doi.org/10.16309/j.cnki.issn.10071776.2003.03.004

[18] Huacani, Y. (2019). Valoración económica del agua para consumo en la ciudad de Juliaca $\quad$ - 2013. http://repositorio.uancv.edu.pe/handle/UA $\mathrm{NCV} / 2674$

[19] Iwan, A., Guerrero, E. M., Romanelli, A., \& Bocanegra, E. (2017). Valoración económica de los servicios ecosistémicos de una Laguna del sudeste bonaerense (Argentina). Investigaciones Geográficas, 68,

173-189. https://doi.org/10.14198/INGEO2017.68.1 0

[20] Jiménez Sotelo, R. A. (2018). El impacto de la ética sobre el crecimiento y el desarrollo: ¿economía ambiental versus economía ecológica? Papers.Ssrn.Com, 23 , 153-182. https://doi.org/10.15381/pc.v23i1.15103
[21] Kervyn, B., Agradezco, *, Figueroa, A., Hopkins, R., Cotlear, D., Gonzales, E., Mayer, E., \& Platteau, J.-P. (1988). La economía campesina en el Perú: Teorías y políticas.

https://centroderecursos.cultura.pe/sites/de fault/files/rb/pdf/La_economia_campesina _en_el Peru_Teorias_y_politicas.pdf

[22] Labandeira, X., León, C., \& Vázquez, M. (2007). Economía Ambiental. In Pearson Educación.

[23] Liu, J., Liu, R., Yang, Z., \& Kuikka, S. (2021). Quantifying and predicting ecological and human health risks for binary heavy metal pollution accidents at the watershed scale using Bayesian Networks. Environmental Pollution, 269, 116125. https://doi.org/10.1016/j.envpol.2020.1161 25

[24] Liu, Y., Guo, T., Wang, R., Engel, B. A., Flanagan, D. C., Li, S., Pijanowski, B. C., Collingsworth, P. D., Lee, J. G., \& Wallace, C. W. (2019). A SWAT-based optimization tool for obtaining costeffective strategies for agricultural conservation practice implementation at watershed scales. Science of the Total Environment, 691, 685-696. https://doi.org/10.1016/j.scitotenv.2019.07 .175

[25] Lustig, N. C., Gray-Molina, G., Higgins, S., Jaramillo, M., Jimenez, W., Paz, V. C., Pereira, C., Pessino, C., Scott, J., \& Yanez, E. (2012). The Impact of Taxes and Social Spending on Inequality and Poverty in Argentina, Bolivia, Brazil, Mexico and Peru: A Synthesis of Results. SSRN Electronic Journal. https://doi.org/10.2139/ssrn.2135600

[26] Machaca, V. H. (2014). Contaminación del rio Torococha en Juliaca (Perú) y su impacto en la salud pública.

[27] Mendoza Bellido, W. (2014). Cómo investigan los economístas? Guía para elaborar y desarrollar un proyecto de investigación.

https://files.pucp.education/departamento/e conomia/lde-2014-05.pdf

[28] Quispe Mamani, J. C. (2015). Eldesarrollo territorial rural $\mathrm{y}$ la sustentabilidad. 
Análisis integrado de la cuenca de río Coata, región Puno, Perú. Revistas.Unap.Edu.Pe. https://doi.org/10.26867/se.2015.2.47

[29] Riera, C. (2013). Entre el riesgo climático $\mathrm{y}$ las transformaciones productivas: la agricultura bajo riego como forma de adaptación en Río Segundo, Córdoba, Argentina. Elsevier. https://www.sciencedirect.com/science/arti cle/pii/S0188461113727869

[30] Santos, F. M. dos, de Oliveira, R. P., \& Mauad, F. F. (2020). Evaluating a parsimonious watershed model versus SWAT to estimate streamflow, soil loss and river contamination in two case studies in Tietê river basin, São Paulo, Brazil. Journal of Hydrology: Regional Studies, $29, \quad 100685$. https://doi.org/10.1016/j.ejrh.2020.100685

[31] Tayyebi, A., Tayyebi, A., Vaz, E., Arsanjani, J. J., \& Helbich, M. (2016). Analyzing crop change scenario with the SmartScape $^{\mathrm{TM}}$ spatial decision support system. Land Use Policy, 51, 41-53. https://doi.org/10.1016/j.landusepol.2015. 11.002

[32] Walker, T. R., MacAskill, D., \& Weaver, P. (2013). Environmental recovery in Sydney Harbour, Nova Scotia: Evidence of natural and anthropogenic sediment capping. Marine Pollution Bulletin, 74(1), 446-452.

https://doi.org/10.1016/j.marpolbul.2013.0 6.013

[33] Wambua, B. N., Japhan Omoke, K., \& Mutua, T. M. (2014). Effects of SocioEconomic Factors on Food Security Situation in Kenyan Dry lands Ecosystem. Asian Journal of Agriculture and Food Science, 02(01), 2321-1571. www.ajouronline.com

[34] Wang, Q., Ko, J. H., Wu, H., Liu, F., \& $\mathrm{Xu}, \mathrm{Q}$. (2021). Impact of bottom ash codisposed with municipal solid waste on geotextile clogging in landfills. Science of The Total Environment, 145744. https://doi.org/10.1016/j.scitotenv.2021.14 5744
[35] Wu, Y., Nehrir, A., Ren, X., Dickerson, R. R., Huang, J., Stratton, P. R., Gronoff, G., Kooi, S., Collins, J., Berkoff, T. A., Lei, L., Gross, B., \& Moshary, F. (2021). Synergistic aircraft and ground observations of transported wildfire smoke and its impact on air quality in New York City during the summer 2018 LISTOS campaign. Science of The Total Environment, 145030. https://doi.org/10.1016/j.scitotenv.2021.14 5030

[36] Xu, L., Wang, T., Ni, K., Liu, S., Wang, P., Xie, S., Meng, J., Zheng, X., \& Lu, Y. (2013). Metals contamination along the watershed and estuarine areas of southern Bohai Sea, China. Marine Pollution Bulletin, 74(1), 453-463. https://doi.org/10.1016/j.marpolbul.2013.0 6.010

[37] Yuan, F., Wei, Y. D., Gao, J., \& Chen, W. (2019). Water crisis, environmental regulations and location dynamics of pollution-intensive industries in China: A study of the Taihu Lake watershed. Journal of Cleaner Production, 216, 311322.

https://doi.org/10.1016/j.jclepro.2019.01.1 77

[38] Zamani-Ahmadmahmoodi, R., EsmailiSari, A., Mohammadi, J., Bakhtiari, A. R., \& Savabieasfahani, M. (2013). Spatial distribution of cadmium and lead in the sediments of the western Anzali wetlands on the coast of the Caspian Sea (Iran). Marine Pollution Bulletin, 74(1), 464-470. https://doi.org/10.1016/j.marpolbul.2013.0 6.009

[39] Zhang, S., Li, Y., Zhang, T., \& Peng, Y. (2015). An integrated environmental decision support system for water pollution control based on TMDL - A case study in the Beiyun River watershed. Journal of Environmental Management, 156, 31-40. https://doi.org/10.1016/j.jenvman.2015.03. 021 